A. P. Falendysh, Dr. Sc. (Tech.), Prof., orcid.org/0000-0003-3602-7945, N. D. Chyhyryk, Cand. Sc. (Tech.), Assoc. Prof., orcid.org/0000-0002-2148-1304,

A. L. Sumtsov, Cand. Sc. (Tech.), orcid.org/0000-0002-3121-9545, O. V. Kletska, orcid.org/0000-0002-4682-860X
Ukrainian State University of Railway Transport, Kharkiv, Ukraine, e-mail: sal-hiit@i.ua

\title{
THE CHOICE OF THE STRATEGY OF TECHNICAL OPERATION OF MODERNIZED SHUNTING LOCOMOTIVES
}

Purpose. The work is devoted to the relevant issue of choosing a technical operation strategy for modernized shunting locomotives. To achieve this goal, the existing indicators evaluating the technical operation components were considered and a new evaluation criterion was proposed.

Methodology. Applying a comprehensive approach to assessing the technical operation effectiveness, a new indicator, a complex technical operation coefficient, was developed. A mathematical model for determining the complex technical operation coefficient was developed.

Findings. The modeling of the change in the scope of unplanned repairs based on the existing requirements to the value of the percentage of faulty diesel locomotive locomotives. The complex technical exploitation coefficient for different strategies of scheduled technical maintenance and repairs is calculated.

Originality. Dependences are obtained for unplanned repairs depending on the percentage of faulty locomotives in and the number of sections at the disposal of the locomotive depot. A new criterion of estimation of systems of technical operation of locomotives is proposed and efficiency of its application is proved.

Practical value. Modeling was carried out for two types of work (shunting and removal) and four maintenance and repair systems. Calculations of the complex technical operation coefficient for modernized shunting locomotives of the YME3M series showed that the change in its value is 3.7-4.25 UAH/kWh. Thus, it is preferable to apply the fourth strategy from the considered maintenance and repair strategies. Due to its application, a rational technical operation system for modernized shunting locomotives of the ЧME3M series with diesel engines Cat 3508 was choosen.

Keywords: technical operation, shunting locomotives, YME3 locomotives

Introduction. The park of shunting diesel locomotives (SL) of Ukrainian railways and industrial enterprises consists of different series. Their overwhelming majority accounts for the diesel YME3 and TEM2 locomotives of different indices. More than $98 \%$ of these locomotives are operated outside the statutory lifetime of 25 years. Only YME3 diesel locomotives are operated at the limit of the normative lifetime, but they will exhaust the assigned resource within the next 3 years. Thus, the issue of upgrading the park becomes very acute.

In accordance with the state renewal programs for the locomotive fleet of the Ukrainian railways for shunting diesel locomotives of the YME3 series, a comprehensive modernization using power plants based on the diesel engines of foreign production was chosen as the main direction. Upgrading for the part of the park through its modernization is a very promising direction. This raises the important issue of choosing a technical operation system

Analysis of the recent research and publications and problem statement. Many publications have been devoted to the issue of choosing a strategy for technical operation. Thus, the reliability of diesel locomotive exploitation in operation was considered in article [1] and the

(C) Falendysh A. P., Chyhyryk N. D., Sumtsov A. L., Kletska O. V., 2019 use of $\mathrm{ABC}$ analysis for the determination of optimal spare parts reserve was proposed. However, the issues of correction or choice for the periodicity were not considered. The definition and correction for the service and repair system of diesel engines is described in [2]. In the article [3], the method of inter-repair intervals correction depending on seasonal operating conditions is considered. As a result, an option from an adjusted technical operation system for shunting diesel locomotives was proposed. However, the results did not take into account the possibility of switching the locomotive equipment strategies and did not consider the impact of unplanned repairs on the technical efficiency factor. The issue of the reliability and repair for the SM48 shunting locomotives operated on the PKP CARGO S.A railway in Poland and assessing the value of their operation is considered in the works $[4,5]$. The possibility of choosing a different maintenance system was not considered. The work [6] is devoted to the determination of the quantitative assessment for the reliability of rolling stock applying the impact analysis of various component failures on the overall reliability of the system. Based on the conducted research, recommendations for the correction of the maintenance system were made. The article [7] proposes a quasiperiodic policy for the preventive maintenance, and the first intervals between repairs are divided into planned and unplanned ones. At subsequent inter- 
vals, there is a nodes replacement in case of their catastrophic failure or achieving a service life limit. The result of this work is an optimized technical maintenance model for diesel locomotives. The work [8] is devoted to the search of the optimal maintenance periodicity for a motorcar rolling stock. The work [9] is devoted to the development of a combined optimization model for the planned repairs periodicity.

In the considered works, the principles of calculating the reliability for shunting locomotive operation and various approaches to adjusting the technical operation systems are widely covered. However, unfortunately, there is no comprehensive approach to the selection and adjustment of the technical operation strategy, which would allow taking into account not only the reliability of the traction rolling stock, but also the effectiveness of its use.

Objectives of the article. The purpose of the study is to create a model for selecting a technical operation system based on a comprehensive approach to determining its effectiveness.

Taking into account the goal set, the following tasks need to be solved:

- analysis of indicators required to evaluate individual technical operation components of shunting diesel locomotives;

- creation of complex technical operation coefficient and the model of its determination based on the results of indicators analysis;

- calculation of the integrated coefficient and the choice of technical operation system for modernized diesel locomotives ЧME3 with diesel Cat 3508;

- assessment of the effectiveness for the selected system of technical operation.

Methodology and model for the choice of rational technical operation strategy. The modernization process involves installing new units on the locomotive. At the same time, there is assembling to a single functional system of nodes from different generations. This leads to complexity of the choice for the technical operation system (TOS). On the one hand, the development of technical solutions allows the use of new approaches to the management of TOS; on the other hand, the use of the chassis part design for the locomotive, which has already been used up to modernization for 25-30 years, requires the application of measures to extend the service life of the bearing structures and control of their condition. In addition, it is difficult to determine the inter-inspection and inter-repair intervals for shunting locomotives due to the wide range of changes in load on the locomotive. This occurs during operation due to the unevenness of the locomotive load at different stations and types of work. If maneuvering, slipping and outsourcing are the direct target use of SL for its intended purpose, then suburban work is related to the need to meet transportation needs in the absence of adequate units of rolling stock. Special work is required to meet the needs of the railways in the performance of certain work due to the lack of special machines. This type of work is mainly seasonal in nature, for example, to clean the contact network from the ice; vibro-pantographs are installed at separate SL in the winter.
Due to such a wide range of work, the assessment of efficiency causes certain difficulties. They relate to the different physical content of the indicators applied to evaluate them.

The general array of indicators characterizing the locomotive operation $P$ consists of separate arrays characterizing the respective direction for the evaluation of the operation system. Thus, it will have the following view from the research for the SL

$$
P=\left\{P_{q n}^{I U} ; P_{q l}^{I U} ; P_{q n}^{M R S} ; P_{q l}^{M R S} ; P_{e k o n} ; P_{i n d}\right\}
$$

where $P_{q n}^{I U}$ is an array of quantified indicators for the intended use system; $P_{q l}^{I U}$ is an array of qualitative indicators for the intended use system; $P_{q n}^{M R S}$ is an array of quantified indicators for the maintenance and repair system; $P_{q l}^{M R S}$ is an array of qualitative indicators for the maintenance and repair system; $P_{q n}^{M R S}$ is an array of economic indicators; $P_{q n}^{M R S}$ is an array of indicators characterizing the design of the locomotive.

As a result of the existing indicators analysis for the main criterion for assessing the intended use system, it is necessary to select the amount of work performed, which is expedient to express for diesel locomotives with electric power transmission through the amount of electric energy produced by traction generators. This indicator allows taking into account the load on the locomotive as a whole and its individual systems. This approach takes into account the particular operational conditions, in which the locomotive is used.

Various indicators are used to assess the effectiveness of the TOR system. They are conventionally divided into arrays of qualitative and quantitative indicators. The array of qualitative indicators for the TOR system consists of reliability indicators (readiness and technical use coefficients, and others), the complexity of carrying out scheduled maintenance, maintenance, repair, overhaul and unplanned repairs (UR). Some of the indicators characterizing the TOR system are economic (total cost of the TOR system, the average cost of UR). Among the above-listed indicators, only the technical use coefficient describes the TOR system to the fullest extent possible, because it takes into account all planned maintenance, PR, overhaul and unplanned repairs.

Using the expert method, the following indicators were chosen from the aggregate of indicators of the $P$ array that allow characterizing the system of technical operation thoroughly: the amount of work performed $A$, the predicted lifetime of $T_{e x}$, the technical use coefficient of the locomotive $K_{T B}$, the total operational costs $C_{E}$, the cost of carrying out unplanned repair of the $C_{U R}$, the total idle time for unplanned repair of $T_{U R}$.

The amount of work performed for different types of work has a different measurement criterion. Thus, for cargo and exportation, it is measured in ton-kilometers of gross freight, for maneuvering and special work - in locomotive-hours of work. All these criteria do not give a complete picture for the load capacity of the locomotive. Ton-kilometer work does not take into account the 
features of the profile and composition (other than its weight). Locomotive-hours of work do not take into account the features of the profile, or the load of a locomotive power plant. When operating stationary and marine power plants based on diesel engines, the number of engine operating hours is used, but this indicator is not feasible for application in locomotives due to the number of its operation modes and a significant proportion of operating time in transient modes. Based on the above, in order to take into account the amount of work done, it is necessary to use another indicator. Therefore, for further calculations, we apply the amount of electric energy produced by the diesel generator during the work. This will take into account a greater number of factors affecting the operation of the diesel locomotive when used in different operating modes. In the case of diesel locomotives with hydraulic transmission of power, it is necessary to install additional sensors for the determination of mechanical energy.

The total operational costs $C_{E}$ shall include all expenses incurred by the locomotive depot on the SL operation. According to [10], the costs of locomotive operation are the costs of the second stage in the life cycle. These costs consist of two main parts: the cost of operating work (intended use) and the cost of the TOR system.

The average cost of unplanned repair $C_{U R}$ is the total cost of UR attributed to the total time spent to eliminate UR $T_{U R}$. The total idle time for UR $T_{U R}$ consists of the total idle time for all URs or the total recovery time.

The generalization of individual indicators is a rather difficult task. For its solution, it is necessary to apply modern approaches. To do this, it is necessary to determine the category, to which the technical operation relates.

According to GOST 25866, the technical operation of a locomotive is a part of the operation, which includes the transportation, storage, maintenance and repair of the locomotive.

Each component of the technical operation is a service aimed at creating and maintaining the ability of the locomotive to realize its purpose. DSTU ISO 9000 provides the following definition for the service. This is the result of at least one action that is necessarily performed in the interaction between the supplier and the customer. In the case of a locomotive TO, it is an action performed by the customer with a locomotive service provider. For instance, the locomotive transport is a transfer of a locomotive by the service provider according to the customer's order. In the conditions of the Ukrainian railways, an example of locomotive transportation is its transfer by other TPC. In particular, this occurs during transport to a factory or another enterprise in a failed state for the implementation of maintenance, repair, overhaul, modernization, utilization or storage.

Taking into account the above, TOR is a kind of service; it is aimed at maintenance and restoration of workability using locomotive by purpose, waiting for the work, storage and transportation.

Thus, the definition of the most rational TO version for SL is to choose from possible strategies, which quality is higher compared to others.
Three methods are used to assess the quality of products in qualimetry:

- differential method - the method of product comparison by comparing the values of individual unit quality indices with the corresponding set of values for the basic indicators;

- complex method - the method of product comparison by means of the definition of a complex index calculated based on the individual indicators;

- mixed method - a method for comparing products using unit and complex indexes.

The complex method of evaluation provides the possibility of direct comparison for different TOSs due to a complex index, therefore, it is the most appropriate to make a decision on the choice for the option.

Complex index of product quality can be expressed in two ways:

- a functional dependence of the main or integral index on the output indicators of product quality;

- a weighted average indicators of product quality.

In the first method, the mathematical model for the process of product intended use determines the functional dependence of the complex index on the output of individual indicators. Complex indexes built on this principle are adequate if the accepted mathematical model corresponds to the actual process of the product intended use.

Traction rolling stock belongs to the active part of the main production assets of rail transport; therefore, for the assessment of technical operation, it is necessary to compare the costs of maintenance and maintaining it in a technically good condition with the result of its work.

Taking into account that based on the previous analysis, the result of the work performed for shunting locomotives is expedient to estimate according to the amount of energy produced, and in its turn, it can be estimated as the average operating value multiplied by the time of intended use, the following expression is obtained

$$
K_{K T E}=\frac{C_{E g e n}}{Q T_{E} K_{T B}},
$$

where $K_{K T E}$ is the complex factor of technical exploitation, UAH/kWh; $C_{\text {Egen }}$ is total operating costs, UAH; $Q$ is a specific amount of electric energy produced, for electric locomotives, $\mathrm{kWh} / \mathrm{h} ; T_{E}$ is duration of operation, h; $K_{T B}$ is the coefficient of technical use.

The total operating costs $C_{E g e n}$ can be divided into two components: fixed scheduled operating costs $C_{E p}$ and the total costs for the elimination of unplanned repairs $C_{\text {URgen. }}$. The latter can be expressed as

$$
K_{K T E}=\frac{C_{E p}+C_{U R} M_{U R}}{Q T_{E} K_{T B}},
$$

where $C_{E p}$ is total operating costs, $\mathrm{UAH} ; C_{U R}$ is average cost of unplanned repair, UAH/repair; $M_{U R}$ is the number of unplanned repairs.

The choice of a rational technical operation system is to find a variant with the smallest value of the complex 
of technical operation index $K_{K T E}$ from among different variants of the TO system. In the implicit form, the target function from the mathematical model will be the following

$$
K_{K T E}\left(T_{E}\right)=f\left(C_{E}\left(T_{E}\right), C_{U}\left(T_{E}\right), Q\left(T_{E}\right), K_{T B}\left(T_{E}\right)\right) \rightarrow \min .
$$

Minimizing for the target function comes from minimizing the cost of maintaining and operating SL. In this case, the amount of energy produced should be as high as possible. In order to calculate the proposed formula, it is necessary to introduce a number of restrictions

$$
\left\{\begin{array}{l}
T_{E}>5 \text { years; } \quad C_{E}>0 ; \quad C_{U R}>0 \\
Q>0 ; \quad T_{U R}<T_{D} ; \quad 0,75<K_{G}<1
\end{array} .\right.
$$

Thus, the use of an integrated approach to the definition of a rational technical operation system takes into account the working conditions and cost estimation for the locomotive operation.

The choice of a rational technical operation system for modernized shunting diesel locomotives YME3M. The modernized diesel locomotive YME3M with diesel Cat3508 was created through the comprehensive modernization of the YME3 series SL with the installation of modern power and auxiliary equipment. Trolleys, the main frame of the locomotive and traction TE006 type motors were taken from locomotive base during the modernization. Other facilities installed are new, including a diesel generator consisting of a diesel engine Caterpillar 3508B with a rated power of $970 \mathrm{~kW}$ and two generators: the main AC-type of the GS523UHL2 type and the additional type ГС 1101УХЛ2. Both generators are produced by SE "Electrotyazhmash".

Four variants of the TOR system (three of which operate on the Ukrainian railways and the variant proposed by the manufacturer) and three variants of the VP system (exploitation in outbound and shunting operations) were considered for the calculation and selection of the rational TO system. Thus, 12 variants of TO systems were calculated.

The degree of the locomotive loading on various types of work is given in Table 1, and inter-repair intervals are selected from [11].

Standards of idling for all systems are the same and equal to: 1.5 hours for TM-2, 12 hours for TM-3, 24 hours for SM-1, 96 hours for SM-2, 120 hours for SM 3.

To determine the UR parameters, we will use the data on the depot percentage of faulty locomotives. In

Table 1

Degree of the locomotive loading at various types of work

\begin{tabular}{|l|c|c|c|c|c|}
\hline \multirow{2}{*}{$\begin{array}{c}\text { Type of } \\
\text { locomotive work }\end{array}$} & \multicolumn{5}{|c|}{ Degree of loading, \% } \\
\cline { 2 - 6 } & Idling & $25 \%$ & $50 \%$ & $75 \%$ & $100 \%$ \\
\hline Shunting & 46 & 40 & 12 & 1.5 & 1.5 \\
\hline Outbound & 67 & 2 & 3 & 3 & 25 \\
\hline
\end{tabular}

accordance with the "Regulations on the planning and warning system of repair and maintenance for the traction rolling stock (electric locomotives, diesel locomotives, electric and diesel trains)" [13] depot percentage of defective locomotives must not exceed $8 \%$.

Such a high percentage of faulty locomotives compared to electric locomotives is associated with a lower equipment reliability of available locomotives due to a significant period of their service.

Let us conduct the modeling for the change in the scope of unplanned repairs. If we set the number of locomotives in operation $M_{E}$ in the interval from 1 to 100 sections, I TOR strategy (Table 1) and the depot percentage of $8 \%$, the change of the scope of unplanned repairs of $F_{U R}$ will have a linear relationship (Fig. 1).

For the first strategy, when changing the depot percentage of faults from 0 to $10 \%$, and changing the number of locomotives in operation, the scope of possible unplanned repairs will be directly proportional to the depot percentage of faulty locomotives and the number of the locomotive park sections (Fig. 2).

If the number of locomotives in the unplanned repair of the $M_{U R}$ is expressed as the ratio of the annual work for the fleet of the locomotive depot to the average exploitation rate for UR $L_{U R}$, that is,

$$
M_{U R}=\frac{365 \cdot M_{E}}{L_{U R}}
$$

and separating the ratio $t_{U R} / L_{U R}$ we get

$$
\frac{t_{U R}}{L_{U R}}=\frac{F_{U R}}{M_{E}} .
$$

At depot percentage of defective locomotives equal to $8 \%$ for different strategies of the TOR we get the following values of $t_{U R} / L_{U R}$ :

$-t_{U R} / L_{U R}=0.0965$ for the first and second strategy;

$-t_{U R} / L_{U R}=0.0963$ for the third strategy;

$-t_{U R} / L_{U R}=0.0967$ for the fourth strategy.

If the depot percentage changes, this ratio will change; however, it does not depend on the number of sections in the locomotive shed park (Fig. 3)

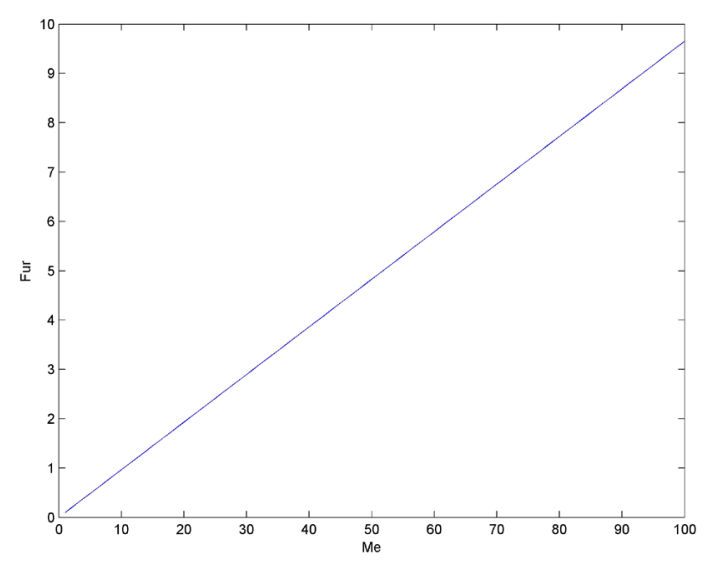

Fig. 1. Dependence of the change in the scope of unplanned repairs $F_{U R}$ on the number of sections in operation $M_{E}$ 


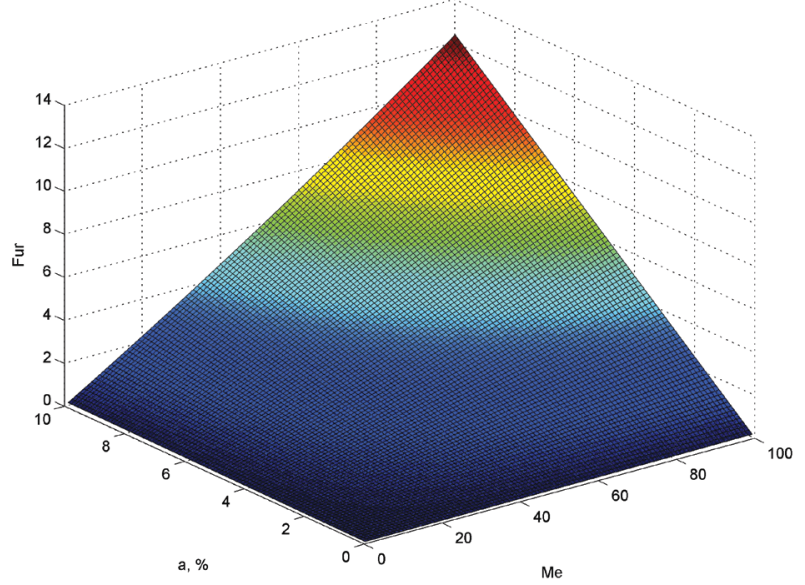

Fig. 2. Dependence of the change in the scope of unplanned repairs $F_{U R}$ on the depot percentage of faulty locomotives and the number of sections in operation $M_{E}$

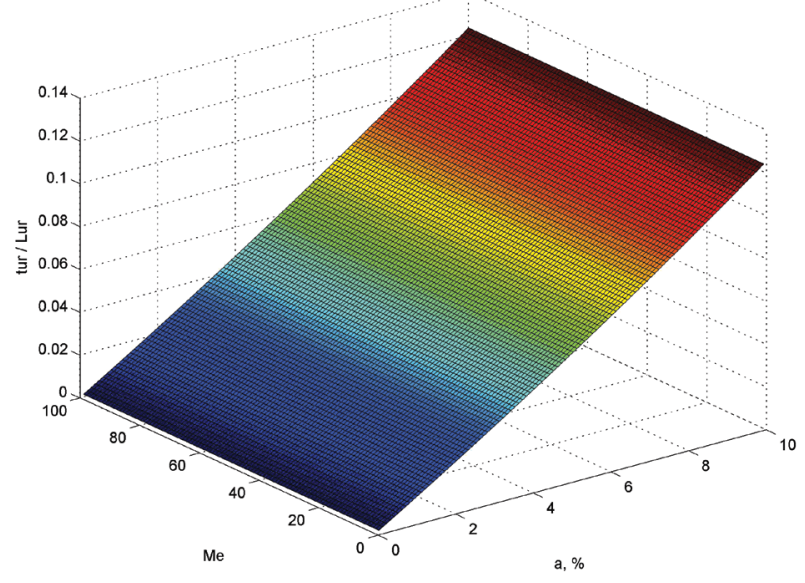

Fig. 3. Dependence of the change in the ratio $t_{U R} / L_{U R}$ on the depot percentage of faulty locomotives $a$ and the number of sections in operation $M_{e}$

The initial data for calculating the rational TO system for YME3 shunting diesel locomotives with Cat 3508 diesel is given in Table 1 and Table 2. The cost of maintenance for the TM, SM and $\mathrm{O}$ is given in Table 3. In carrying out the $\mathrm{O}$, we take into account the conduct of the TM-5 before and after the overhaul. To calculate

Table 2

Cost and duration of maintenance, SM and CD

\begin{tabular}{|c|l|c|c|}
\hline № & $\begin{array}{c}\text { Type of TM, } \\
\text { SM and O }\end{array}$ & $\begin{array}{c}\text { Cost of carrying } \\
\text { out, UAH }\end{array}$ & Duration, hours \\
\hline 1 & TM-2 & 912 & 1.5 \\
\hline 2 & TM-3 & 18280 & 12 \\
\hline 3 & SM-1 & 34407 & 24 \\
\hline 4 & SM-3 & 600681 & 120 \\
\hline 5 & TM-4 & 10280 & 6 \\
\hline 6 & O-1+ TM-5 & 2894490 & 744 \\
\hline 7 & O-2+ TM-5 & 3196900 & 744 \\
\hline
\end{tabular}

the change in the technical use coefficient we apply the dependencies [12]. The calculation results are shown in Figs. 4 and 5.

As a result of the simulation, we obtain a change in the coefficient with constant growth during the LC. It is evident from the figures that jumps in the coefficient change occur at the time of the overhaul. This is due to relatively high costs for the overhaul and sometimes a downtime during the overhaul.

The discount factor $\alpha$ is used to compare different costs over time. It allows taking into account different time-based costs for the base year. It is calculated with the formula

$$
\alpha_{t}=\left(1+E_{H}\right)^{t_{p}-t}
$$

where $E_{H}$ is the discount rate; $t_{p}$ is estimated year; $t$ is the year, whose expenses are given to the estimated year.

If operating diesel locomotives for 25 years and using initial runway as an estimated year, the change in the discount factor takes the form shown in Fig. 6.

Taking into account the discount factor, the complex index will have the form shown in Figs. 7 and 8.

Thus, for all types of work, the fourth TOR strategy will be rational by the complex technical operation index.

Estimation of efficiency for the implementation of a rational technical operation system for shunting diesel locomotives YME3M. Implementation of any technology

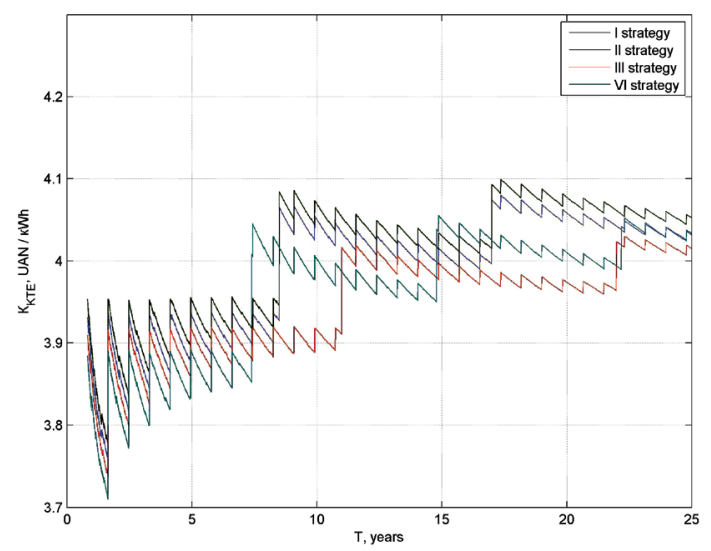

Fig. 4. Complex index for operation on shunting work

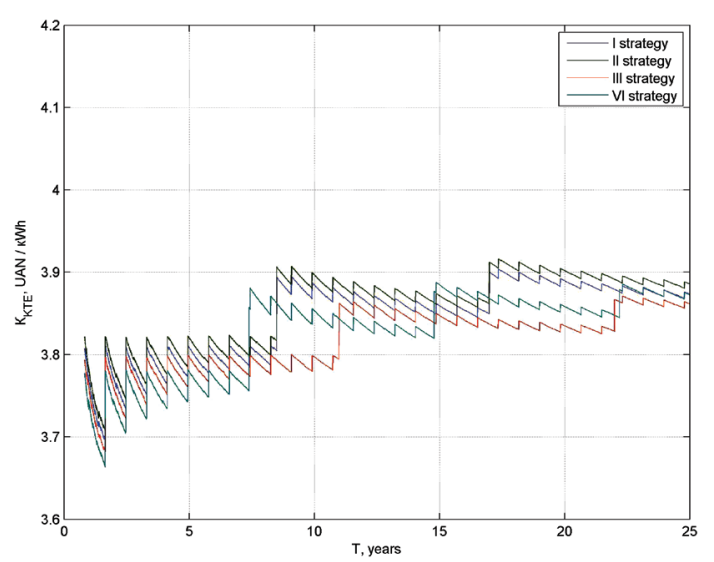

Fig. 5. Complex index for operation on outbound work 


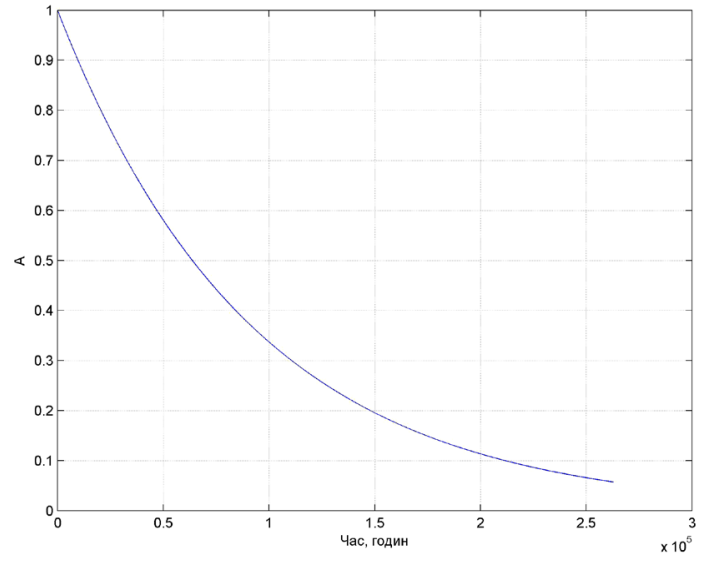

Fig. 6. Changing the discount rate for 25 years

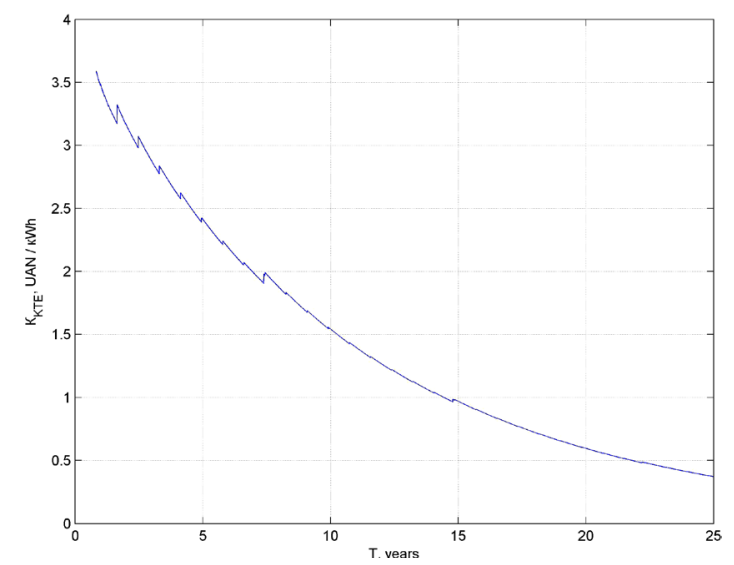

Fig. 7. Change in the complex technical operation index for the modernized shunting diesel locomotive on shunting operation taking into account the discount factor

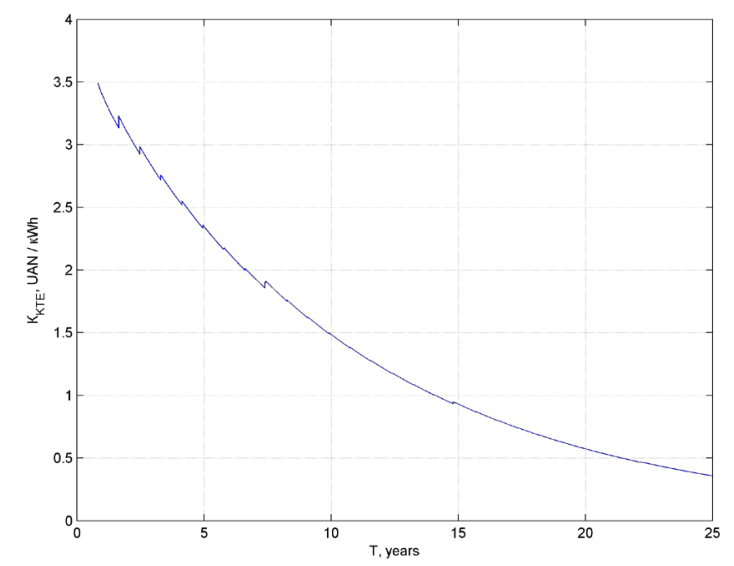

Fig. 8. Change in the complex technical operation index for the modernized shunting diesel locomotive on outbound operation taking into account the discount factor

and engineering decisions must be made by assessing the effectiveness of their use compared with existing ones. The economic effect for the introduction of rational TO system of SL is the effectiveness of economic activity, the implementation of economic programs and measures, characterized by the difference between the result and the existing approach. That is, for the case of determining the economic effect of introducing a rational TO system, we will have savings (or losses) compared with the existing system.

Thus, the economic effect was determined using the following formula

$$
E_{E}=C_{T E 1}-C_{T E R}
$$

where $E_{E}$ is economic effect, $\mathrm{UAH} ; C_{T E 1}$ is expenditures on the existing TO system, UAH; $C_{T E R}$ is expenditures on the rational TO system, UAH.

The first strategy used for diesel locomotives पME3 with a normative term of service is considered as the existing TO system for SL. According to the calculations carried out above, strategy number four is defined as the rational TO system. The results of calculating the economic effect for SL at shunting work are shown in Fig. 9.

They indicate the feasibility of applying the fourth strategy. The economic effect of its application is 2.86 million UAH per one SL. The economic effect from the application of a rational TO system based on a discount during the LC is 32.37 million UAH per one SL. For the outbound work, the change in the economic effect has a similar appearance. It will amount to 548.11 thousand $\mathrm{UAH}$, taking into account the discount of 6.18 million UAH.

As a criterion for assessing the technological efficiency, we apply the technical use coefficient. Comparing its value to a rational TO system with an existing one, we obtain the magnitude of the increase in the use of SL in percentages

$$
E_{T}=\frac{\left(K_{T B 1}-K_{T B R}\right)}{K_{T B 1}} 100 \%,
$$

where $E_{T}$ is technological effect; $K_{T B 1}$ is the technical use coefficient of the existing TO system; $K_{T B R}$ is the technical use coefficient of the rational TO system.

Fig. 10 shows the change in the technical use coefficient over the life cycle of a rational system compared with the currently used system.

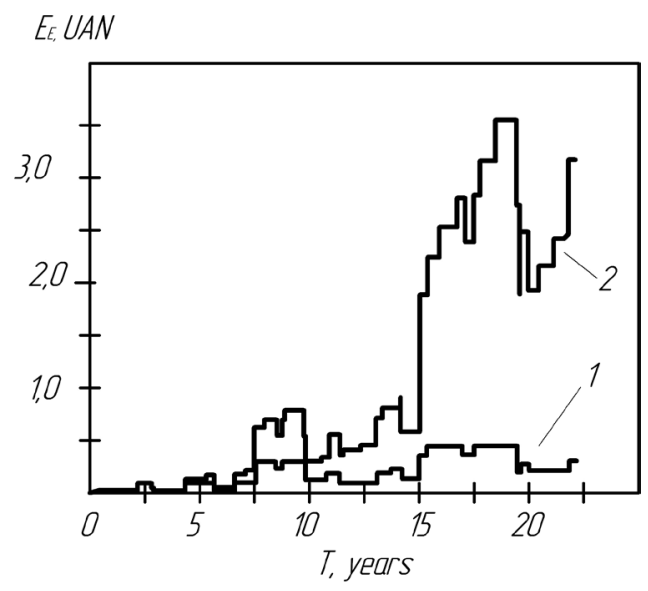

Fig. 9. Change in the economic effect from the introduction of a rational TO system during the SL maneuvering work without discounting (1) and taking it into account (2) 


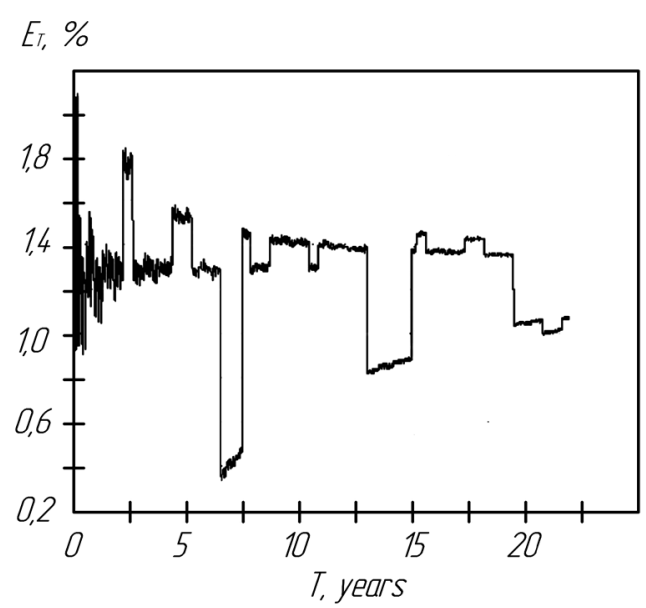

Fig. 10. Change in the of technical use coefficient of modernized SL YME3 from the implementation of a rational TO system during shunting work

\section{Conclusions.}

1. The model for choosing a technical operation strategy for shunting locomotives based on the complex approach and complex technical operation coefficient is proposed. The developed model for finding the complex technical operation index allows taking into account the features of both the operation polygon and the accepted system of technical operation.

2. The complex technical operation coefficient of locomotives, which comprehensively characterizes the process of technical operation of a locomotive, is proposed.

3 . The simulation of the change in the scope of unplanned repairs is carried out depending on the size of the depot percentage of faulty locomotives and locomotive depot locomotive fleet. The dependencies for the change in the scope of unplanned repairs on the depot percentage of faulty locomotives, the number of sections in operation and the accepted maintenance and repair strategy were obtained.

4. Using the proposed model for the choice of the technical operation strategy, a modeling of the technical operation of the shunting locomotives for two systems of intended use and four maintenance and repair systems was conducted.

5. Calculations of the integrated technical operation coefficient for modernized shunting diesel locomotives of the UME3M series proved that the fourth strategy for maintenance and repair for shunting, exportation and loading work is the most expedient. The change in the integrated coefficient was 3.7-4.25 UAH/kWh.

6 . To assess the feasibility of introducing the selected technical operation system of modernized shunting diesel locomotives from an economic point of view, a calculation of the economic effect from the use of a rational technical operation system compared with the existing system was performed. The economic effect at carrying out shunting work is 2.86 million UAH. The economic effect from the use of a rational technical operation system for modernized shunting diesel locomotives in the outbound work will be 448.11 thousand UAH, and 3.1843 million UAH taking into account the discount.
7. Evaluation of technological efficiency for the introduction of a rational technical operation system for a modernized shunting diesel locomotive was carried out by simulating the technical use coefficient for the existing and rational technical operation systems. As a result, the data confirming that the use of a rational technical operation system for upgraded diesel locomotives can increase the technical use rate from 0.35 to $2.1 \%$ during operation was obtained.

8. As a result of the calculations for modernized diesel YME3 locomotives with a diesel Cat-3508, the rational technical operation system will be the fourth strategy proposed by the factory-manufacturer performed the modernization. Its implementation will reduce costs for the current maintenance of locomotives with a simultaneous increase in the technical use coefficient.

\section{References.}

1. Kunar, S., Ghosh, G., Mandal, K., Bose, D. and Sau, S.P., 2013. Measurement and Evaluation of Reliability, Availability and Maintainability of a Diesel Locomotive Engine. IOSR Journal of Mechanical and Civil Engineering, 8(1), pp. 31-46.

2. Bodnar, B. and Ochkasov, O., 2017. System Choice of the Technical Maintenance of Locomotives Equipped with on-Board Diagnostic Systems. In: Transport Means: Proceedings of $21^{\text {st }}$ International Scientific Conference, September 20-22, 2017. Kaunas University of Technology Klaipeda University. Juodkrante, Kaunas, Lithuania [online], pp. 43-47. Available at: <http://eadnurt. diit.edu.ua/jspui/handle/123456789/10203> [Accessed 5 November 2017].

3. Gandhare, S. N., Madankar, T.A. and Ikhar, D. R., 2014. Re-Scheduling Of Maintenance Tasks for Diesel Locomotive (ZDM) Maintenance Work Using FMEA Technique - An Industrial Engineering Approach for Saving the Resources. OSR Journal of Mechanical and Civil Engineering (IOSR-JMCE) International Conference on Advances in Engineering \& Technology, 2014 (ICAET-2014) [pdf], pp. 47-54. Available at: <http:// www.iosrjournals.org/iosr-jmce/papers/ICAET-2014/ me/volume-4/11.pdf> [Accessed 11 September 2017].

4. Szkoda, M., 2014. Analysis of reliability, availability and maintainability (RAM) of SM48 diesel locomotive. In: EURO-ZEL $201422^{\text {nd }}$ International Symposium $3^{\text {rd }}-$ $4^{\text {th }}$, June 2014, Žilina, SK [pdf], pp. 1-10. Available at: $<$ http://m8.mech.pk.edu.pl/ szkoda/pdf/33_ZU_ ZEL\%20MSzkoda.pdf> [Accessed 11 September 2017]. 5. Szkoda, M. and Kaczor, G., 2017. RAMS analysis of railway vehicles' lifecycle. Journal of KONBiN, 41, pp. 83-105.

6. Conradie, P.D., 2015. Quantifying system reliability in rail transportation in an ageing fleet environment./ P. D. Conradie. South African Journal of Industrial Engineering, 26(2), pp. 128-142. DOI:10.7166/26-2-1076.

7. Gao, W., Zhang, Z., Zhou, Y., Wang, R. and Jiang, L., 2013. Optimal quasi-periodic preventive maintenance policies for a repairable system with stochastic maintenance interval. Eksploatacja i Niezawodność, 15(2), pp. 89-98.

8. Corman, F., Kraijema, S., Godjevac, M. and Lodewijks, G., 2017. Optimizing preventive maintenance poli- 
cy: A data-driven application for a light rail braking system. Proceedings of the Institution of Mechanical Engineers, Part O: Journal of Risk and Reliability, 231(5), pp. 534-545. DOI: 10.1177/1748006X17712662.

9. Hryshechkina, T.S., 2017. Mathematical model of the rational maintenance system of railway transport technical objects. Collection of research papers of DNURT named after acad. V. Lazaryan, 14, pp. 30-35.

10. Falendysh, A. P., Sumtsov, A. L. and Kletska, O. V., 2015. Issues of modernization of diesel-electric locomotive taking into account their life cycle. Lokomotive-inform, 1(103), pp. 4-9.

11. Falendysh, A.P., Sumtsov, A. L., Artemenko, O. V. and Kletska, O. V., 2016. Simulation of changes in the coefficient of technical use of shunting locomotives for various systems maintenance. Eastern-European Journal of Enterprise Technologies, 1(79(3)), pp. 19-23. DOI: 10.15587/1729-4061.2016.60640.

12. Ukrzaliznytsia, 2015. The provisions of planned preventive maintenance system repair traction rolling stock (electric locomotives, diesel locomotives, electric and diesel trains). Kyiv.

\section{Вибір стратегії технічної експлуатації модернізованих маневрових тепловозів}

\section{А. П. Фалендиш, Н. Д. Чигирик, А. Л. Сумцов,} О. В. Клецька

Український державний університет залізничного транспорту, м. Харків, Україна, e-mail: sal-hiit@i.ua

Мета. Робота присвячена актуальному питанню вибору стратегії технічної експлуатації для модернізованих маневрових тепловозів. Для досягнення поставленої мети розглянуті існуючі показники складових частин технічної експлуатації та запропоновано новий критерій оцінки.

Методика. Застосовуючи комплексний підхід до оцінки результативності технічної експлуатації, був розроблений новий показник - комплексний коефіцієнт технічної експлуатації. Розроблена математична модель визначення комплексного коефіцієнта технічної експлуатації.

Результати. Проведене моделювання зміни фронту непланових ремонтів на базі існуючих вимог до величини відсотка несправних тепловозів локомотивного депо. Розраховано комплексний коефіцієнт технічної експлуатації для різних стратегій планових технічних обслуговувань і ремонтів.

Наукова новизна. Отримані залежності непланових ремонтів від відсотка несправних локомотивів і кількості секцій, що знаходяться в розпорядженні локомотивного депо. Запропоновано новий критерій оцінки систем технічної експлуатації локомотивів і доведена ефективність його застосування.

Практична значимість. Проведене моделювання для двох видів робіт (маневрової та вивізної) і чотирьох систем технічного обслуговування й ремонту. Розрахунки комплексного коефіцієнта технічної експлуатації для модернізованих маневрових тепловозів серії ЧМЕЗМ показали, що зміна його величини становить $3,7-4,25$ грн/кВт · год. Таким чином, із розгля- нутих стратегій технічного обслуговування й ремонту краще використовувати четверту стратегію. У результаті іiі застосування вибрана раціональна система технічної експлуатації для модернізованих маневрових тепловозів серії ЧМЕЗМ із дизелями Cat 3508.

Ключові слова: технічна експлуатація, маневрові тепловози, тепловози ЧМЕЗ

\section{Выбор стратегии технической эксплуатации модернизированных маневровых тепловозов}

\section{А. П. Фалендыш, Н. Д. Чигирик, А. Л. Сумцов, О. В. Клецкая}

Украинский государственный университет железнодорожного транспорта, г. Харьков, Украина, e-mail: sal-hiit@i.ua

Цель. Работа посвящена актуальному вопросу выбора стратегии технической эксплуатации для модернизированных маневровых тепловозов. Для достижения поставленной цели рассмотрены существующие показатели составляющих частей технической эксплуатации и предложен новый критерий оценки.

Методика. Применяя комплексный подход к оценке результативности технической эксплуатации, был разработан новый показатель - комплексный коэффициент технической эксплуатации. Разработана математическая модель определения комплексного коэффициента технической эксплуатации.

Результаты. Проведено моделирование изменения фронта неплановых ремонтов на базе существующих требований к величине процента неисправных тепловозов локомотивного депо. Рассчитан комплексный коэффициент технической эксплуатации для разных стратегий плановых технических обслуживаний и ремонтов.

Научная новизна. Получены зависимости неплановых ремонтов от процента неисправных локомотивов и количества секций, которые находятся в распоряжении локомотивного депо. Предложен новый критерий оценки систем технической эксплуатации локомотивов и доказана эффективность его применения.

Практическая значимость. Проведено моделирование для двух видов работ (маневровой и вывозной) и четырёх систем технического обслуживания и ремонта. Расчеты комплексного коэффициента технической эксплуатации для модернизированных маневровых тепловозов серии ЧМЕЗМ показали, что изменение его величины составляет 3,74,25 грн/кВт · ч. Таким образом, из рассмотренных стратегий технического обслуживания и ремонта предпочтительнее использовать четвертую стратегию. В результате ее применения выбрана рациональная система технической эксплуатации для модернизированных маневровых тепловозов серии ЧМЭЗМ с дизелями Cat 3508.

Ключевые слова: техническая эксплуатация, маневровые тепловозы, тепловозы ЧМЭЗ

Рекомендовано до публікації докт. техн. наук Ю. С.Калабухіним. Дата надходження рукопису 27.12.17. 